Thorax, 1978, 33, 579-595

\title{
The electron microscopy of "fibrinoid necrosis" in pulmonary arteries
}

\author{
DONALD HEATH AND PAUL SMITH
}

From the Department of Pathology, University of Liverpool L69 3BX, UK

\begin{abstract}
Heath, D, and Smith, P (1978). Thorax, 33, 579-595. The electron microscopy of "fibrinoid necrosis" in pulmonary arteries. Fibrinoid necrosis was induced in the pulmonary arteries of five male Wistar albino rats by feeding them on a diet adulterated by the addition of $0.07 \%$ ground Crotalaria spectabilis seeds by weight. Electron microscopy of the arteries affected by the process showed fibrin in the thrombus occluding their lumens and in the arterial intima, held up from further penetration of the media by the inner elastic lamina. Naturally occurring gaps in this lamina were found, and it is postulated that they determine the characteristic histological configuration of fibrinous vasculosis. The smooth muscle cells of the media of the pulmonary veins showed clear evaginations, devoid of myofilaments and organelles, indicative of sustained constriction compatible with viability of the cells. In contrast, the smooth muscle cells of the media of the pulmonary arteries showed loss of myofilaments leading to frank necrosis.

Other cells seen in the media include fibrocytes and "vasoformative reserve cells." The authors consider that the latter have considerable and varied potential. Once liberated during the process of fibrinoid necrosis in the arterial media they may play an important part in pulmonary vascular pathology as, for example, in the formation of the plexiform lesion.
\end{abstract}

When arteries are subjected to severe hypertension, especially if its development has been rapid, their medial coats become swollen and show areas of an amorphous, homogeneous granular material that is refractile, stains deeply with eosin, and resembles fibrin. Because of this, the process in arterial walls is commonly referred to as "fibrinoid necrosis." An inflammatory cellular exudate, usually composed of neutrophil polymorphs, appears around the affected areas so that the alternative designation of "necrotising arteritis" is also commonly applied. Fibrinoid necrosis occurs in the systemic circulation as a hallmark of "malignant hypertension." It is also found in the pulmonary circulation in a wide group of diseases including mitral stenosis (Elkeles and Glynn, 1946; Hicks, 1953), patent ductus arteriosus with severe pulmonary hypertension (Hultgren et al, 1953), Eisenmenger's complex (Old and Russell, 1950), and primary pulmonary hypertension (Symmers, 1952; Shepherd et al, 1957).

The term "fibrinoid" has come to be applied to a variety of lesions in many diseases, generally based on hypersensitivity or hypertension. As a result, the nature of the materials that have come to be called fibrinoid has become even wider to include, as well as fibrin, altered ground substance, degraded collagen and nucleoprotein, and focal precipitates of gammaglobulin in an area of antigen-antibody reaction (Robbins, 1967). This has led Gardner (1970) to declare that "the term fibrinoid belongs to an age of pathology before the cryostat, the integrating microdensitometer, and the technique of immunofluorescence, methods which could be used to establish the chemical identity of eosinophilic aggregates in damaged tissue." Accepting the general tenor of this argument, we decided to study at least the ultrastructural, if not the chemical, components of fibrinoid necrosis in the pulmonary circulation. We chose as our animal model the necrotising arteritis that is induced in a third of rats fed on a diet containing seeds of Crotalaria spectabilis.

\section{Method and materials}

Five adult male Wistar albino rats $(\mathrm{T} 1-5)$ were fed for seven weeks on a diet containing $0.04 \%$ ground $C$ spectabilis seeds by weight. The percentage of the seeds was then increased to $0.07 \%$ for the re- 
mainder of the experiment. The rats were killed after they had survived on this diet for respectively 16, 19, 22, 22, and 26 weeks. All five animals developed pronounced right ventricular hypertrophy as indicated by a ratio of left to right ventricular weight of less than 2.0 (see table). This right ventricular hypertrophy was taken to have been induced by hypertensive pulmonary vascular disease, which was subsequently confirmed on histological examination. The total body weights and the individual weights of the cardiac ventricles in the test animals are shown, together with the length of survival in the test animals, in the table.

Table Survival and body and cardiac weights in five rats fed on a diet containing Crotalaria spectabilis seeds

\begin{tabular}{|c|c|c|c|c|c|}
\hline \multirow{2}{*}{$\begin{array}{l}\text { Rat } \\
\text { No }\end{array}$} & \multirow{2}{*}{$\begin{array}{l}\text { Survival } \\
\text { in } \\
\text { weeks }\end{array}$} & \multirow{2}{*}{$\begin{array}{l}\text { Initial } \\
\text { body } \\
\text { weight }(g)\end{array}$} & \multicolumn{2}{|c|}{ Cardiac weights $(g)$} & \multirow[t]{2}{*}{$L V+S / R V$} \\
\hline & & & $L V+S$ & $\boldsymbol{R} V$ & \\
\hline $\mathbf{T} 1$ & 16 & 115 & 0.417 & $0 \cdot 374$ & $1 \cdot 11$ \\
\hline T2 & 19 & 115 & 0.474 & 0.333 & $1 \cdot 42$ \\
\hline T3 & 22 & 125 & 0.560 & 0.400 & $1 \cdot 40$ \\
\hline T4 & 22 & 115 & 0.482 & 0.375 & $1 \cdot 29$ \\
\hline T5 & 26 & 125 & 0.520 & 0.450 & $1 \cdot 16$ \\
\hline
\end{tabular}

\section{Results}

\section{HISTOLOGICAL APPEARANCES}

All five test animals showed fibrinoid necrosis of their muscular pulmonary arteries. Focal areas of the media showed replacement by refractile, eosinophilic, homogeneous material. Affected arcs of the arterial media were swollen. Individual muscle cells within these areas appeared to be swollen and granular and their cytoplasmic edges were irregular. Their nuclei appeared swollen and basophilic, and some cells also had a ragged, basophilic cytoplasm. Individual muscle cells were widely separated by pale eosinophilic ground substance that gave a positive staining reaction with alcian blue but not with the periodic-acid Schiff (PAS) technique. The affected arteries contained thrombi, and sections stained by the Martius scarlet blue technique showed fibrin not only within the thrombus but also in the inner parts of the arterial wall where it appeared to be held up by the inner elastic lamina.

\section{ELECTRON MICROSCOPY}

Electron microscopy showed that the thrombi in the muscular pulmonary arteries affected by fibrinoid necrosis were composed of blood platelets and fibrin (fig 1). Much of the fibrin was adherent to the inner surface of the ground substance of the intima, the endothelial covering of which was often discontinuous. The ground substance of the 음 intima together with the inner elastic lamina ap- $\frac{\bar{m}}{\bar{D}}$ peared to form a barrier making further penetra- $\mathbb{\mathbb { D }}$ tion of the arterial wall by the fibrin difficult for it was held up in a ring at the outer margin of $\$$ these structures (fig 2). In a few vessels, however, $\overrightarrow{0}$ the fibrin had penetrated beyond the internal $\overrightarrow{\vec{\omega}}$ elastic lamina, small clumps of fibrin being found $\stackrel{\omega}{\omega}$ between smooth muscle cells within the media. $\overrightarrow{2}$ Confirmation that the strands were composed of fibrin was obtained by the demonstration that they exhibited a periodicity of $20.8 \mathrm{~nm}$ (fig 3). This is $i$ close to the periodicity of $23 \mathrm{~nm}$ measured by 0 Hall (1963) from purified extracts of coagulated 응 fibrinogen. The fibrin was dense rather than fibrillary and was deposited in discrete cigar-shaped $O$ clumps (fig 4). At several points along the length of the inner elastic lamina there were deficiencies allowing continuity between the tissues of the intima and of the media (fig 5). We consider that $\vec{\varphi}$ these deficiencies are important in determining the further penetration of fibrin into the wall of 0 the pulmonary artery (see discussion). Arteries affected by fibrinoid necrosis were also infiltrated by a few neutrophil polymorphs scattered throughout the media and adventitia.

The smooth muscle cells showed striking $\stackrel{2}{\Rightarrow}$ changes in both pulmonary arteries and veins. In the pulmonary veins there were evaginations of $\frac{3}{J}$ the cytoplasm of smooth muscle cells through the endothelial basal lamina to press on to the undersurface of the endothelial cells (fig 6). These evaginations had clear cytoplasm devoid of myofilaments and organelles (fig 6). The muscle cells $\stackrel{\times}{\circ}$ of the media of the muscular pulmonary arteries 3 also showed a lack of myofilaments, but in this case the cell cytoplasm was not clear as in the venous muscle but was dark and granular (fig 7). In some areas of the media the smooth muscle cells appeared to have undergone necrosis and disintegration, with liberation of organelles and fragments of cytoplasm into the ground substance $\mathcal{N}$ of the surrounding media (fig 8). This change was $N$ found only in a few pulmonary arteries, however, N and was not always associated with the presence $\omega$ of fibrin. The cells within the media were widely separated by ground substance (fig 9 ), which took $\varrho$ the form of irregular lamellae of amorphous $\stackrel{\Phi}{\infty}$ material arranged in a haphazard fashion. Beneath the endothelium, however, these lamellae of $\frac{0}{0}$ ground substance were arranged in concentric $\underset{\mathbb{D}}{\mathbb{D}}$ rows and resembled a succession of basal laminae $\frac{O}{\mathbb{D}}$ (fig 10). As a consequence the space between the $\varrho$ endothelium and internal elastic lamina was greatly increased. Mixed with the ground sub- o 


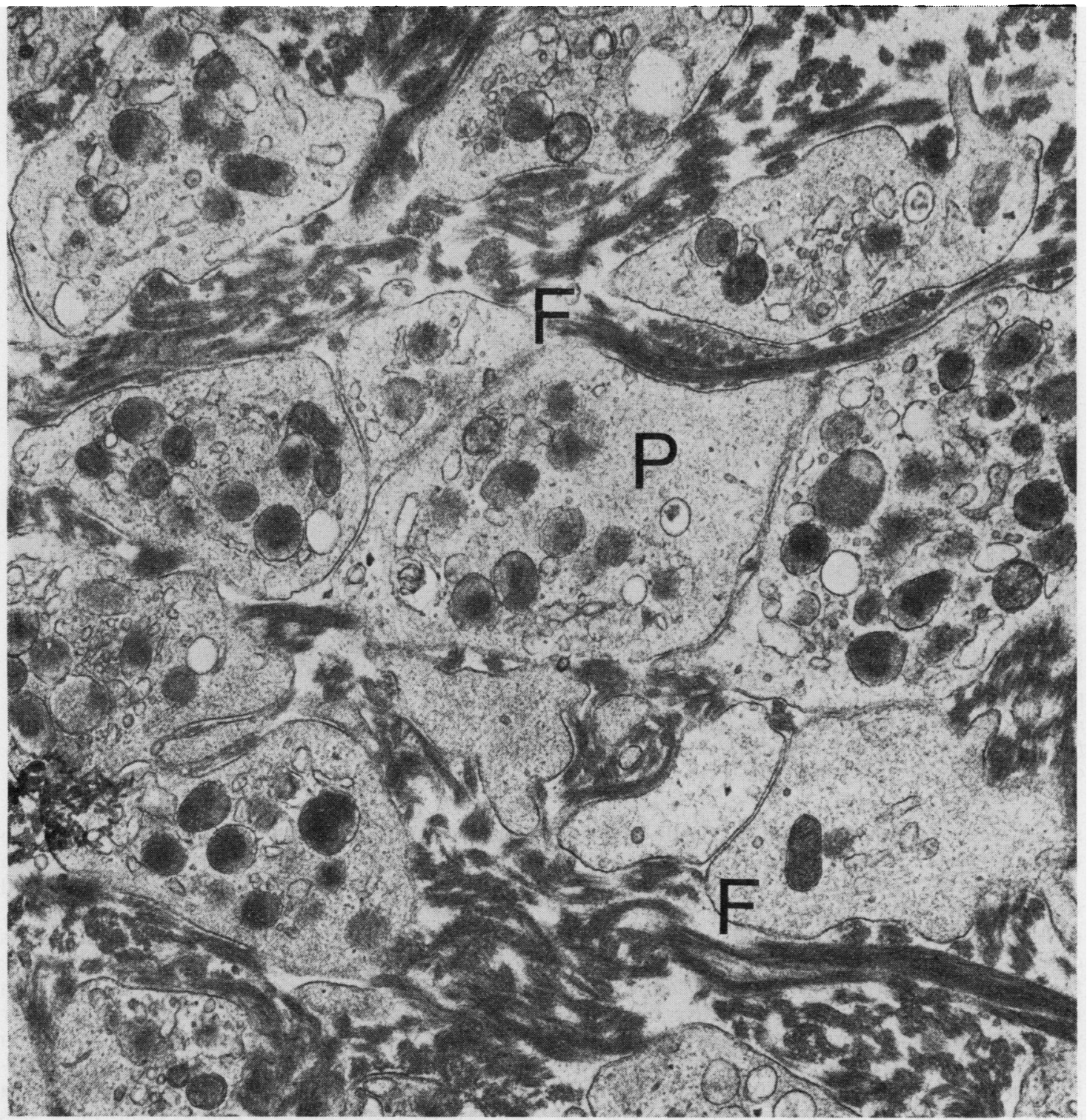

Fig 1 Thrombus occluding one of muscular pulmonary arteries showing fibrinoid necrosis. It consists of blood platelets, $P$, and strands of fibrin, $F($ Electron micrograph $\times 23$ 958). 


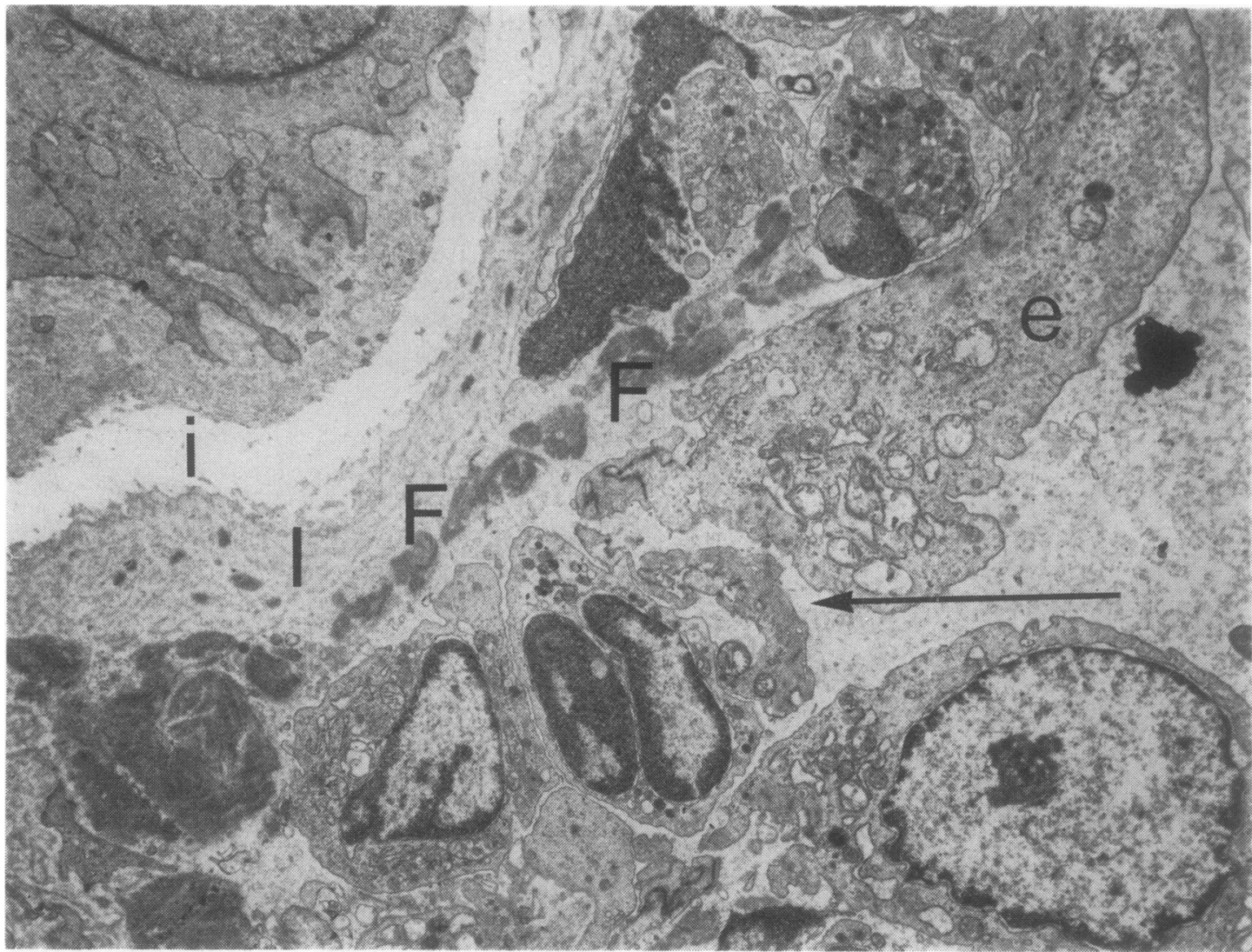

Fig 2 Part of transverse section of a muscular pulmonary artery from rat T4 that showed fibrinoid necrosis. Fine fibrillary fibrin, $F$, is situated beneath endothelial cells $(e)$ and appears to be held up from further penetration of arterial wall by intima, $I$, and internal elastic lamina, $i$. There is a break in continuity of endothelium (arrow) $(E M \times 6635)$.

stance were smaller quantities of elastin and fine collagen fibrils.

Many of the healthy smooth muscle cells showed fine fibrils radiating from their limiting membranes (fig 11). These fibrils merged imperceptibly with striated collagen filaments. Apart from muscle various other cells were found in the media. Some were undoubtedly active fibroblasts with a characteristic profuse open endoplasmic reticulum (fig 12). Their nuclei sometimes had a bizarre appearance due to extensive invagination of its membrane. The nature of other cells was not so immediately apparent. Some had a profuse cytoplasm containing haphazardly arranged fibrils without focal condensations; these cells also contained numerous vesicles, many of which were gathered at the cytoplasmic edge (fig 13). We believe these cells to be what have been termed "vasoformative reserve cells" (see discussion).
Cells with an intermediate appearance were also found that had the open endoplasmic reticulumo of a fibroblast together with peripherally dispersed parallel myofilaments like those of smooth muscle.? "me have termed these intermediate cells

The pulmonary arterioles were muscularised witho a layer of smooth muscle cells bounded by innenN and outer elastic laminae (fig 14). In contrast to the smooth muscle cells of the muscular pulmonary arteries, those of the pulmonary arterioles? showed no ultrastructural changes and there was? no permeation of the arteriolar wall by fibrin (fig 14).

\section{Discussion}

Our electron microscopic studies confirm that in fibrinoid necrosis of pulmonary arteries fibrin is 


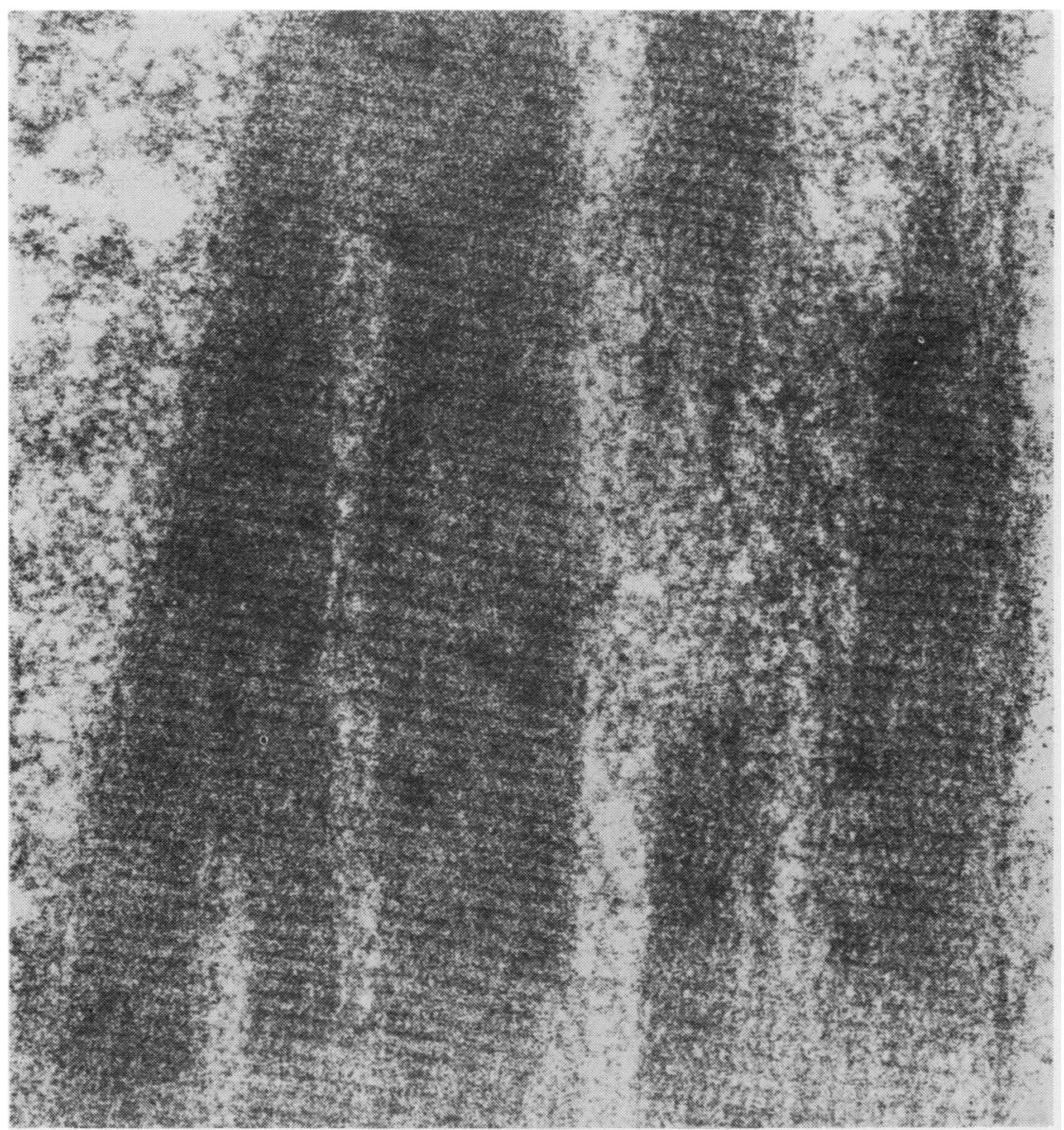

Fig 3 Fibrin strands showing cross banding of $20 \cdot 8 \mathrm{~nm}$ periodicity $(E M \times 100000)$.

forced into their walls from the lumen. They have also confirmed that the fibrin is deposited under the endothelium and accumulates on the inner side of the internal elastic lamina. Lendrum (1955) called this process "fibrinous vasculosis." $\mathrm{He}$ was well aware that the fibrin then breaks through the inner elastic lamina to traverse the media only to get held up once again at the outer elastic lamina where it may spread circumferentially on its inner surface. Finally, it may fan out into the adventitia. Elsewhere we have illustrated the very characteristic histological picture of radial spokes of fibrin joining two concentric rings either side of the media (Wagenvoort et al, 1964). Such a histological picture in fibrinoid necrosis in pulmonary arteries is elegantly demonstrated by the picro-Mallory or Martius scarlet blue stains. Our present study has shown deficiencies in the inner elastic lamina (fig 5), which are a normal feature of the ultrastructure of the pulmonary artery and which offer an explanation for the escape into the media of fibrin held back elsewhere around the circumference of the vessel by the elastic lamina. In this investigation, however, penetration of the media by fibrin had occurred in only a few arteries.

It should be emphasised that in our study the presence of fibrin within pulmonary arteries was not necessarily associated with medial necrosis, but was invariably found in connection with breaks in the endothelium. The term fibrinoid necrosis in this context is thus a misnomer, and the term fibrinois vasculosis (Lendrum, 1955) is to be preferred. Similar light and electron microscopic appearances have been described by Merkow and Kleinerman (1966) in the pulmonary arteries of rats given monocrotaline. These workers found amorphous deposits of fibrin within 


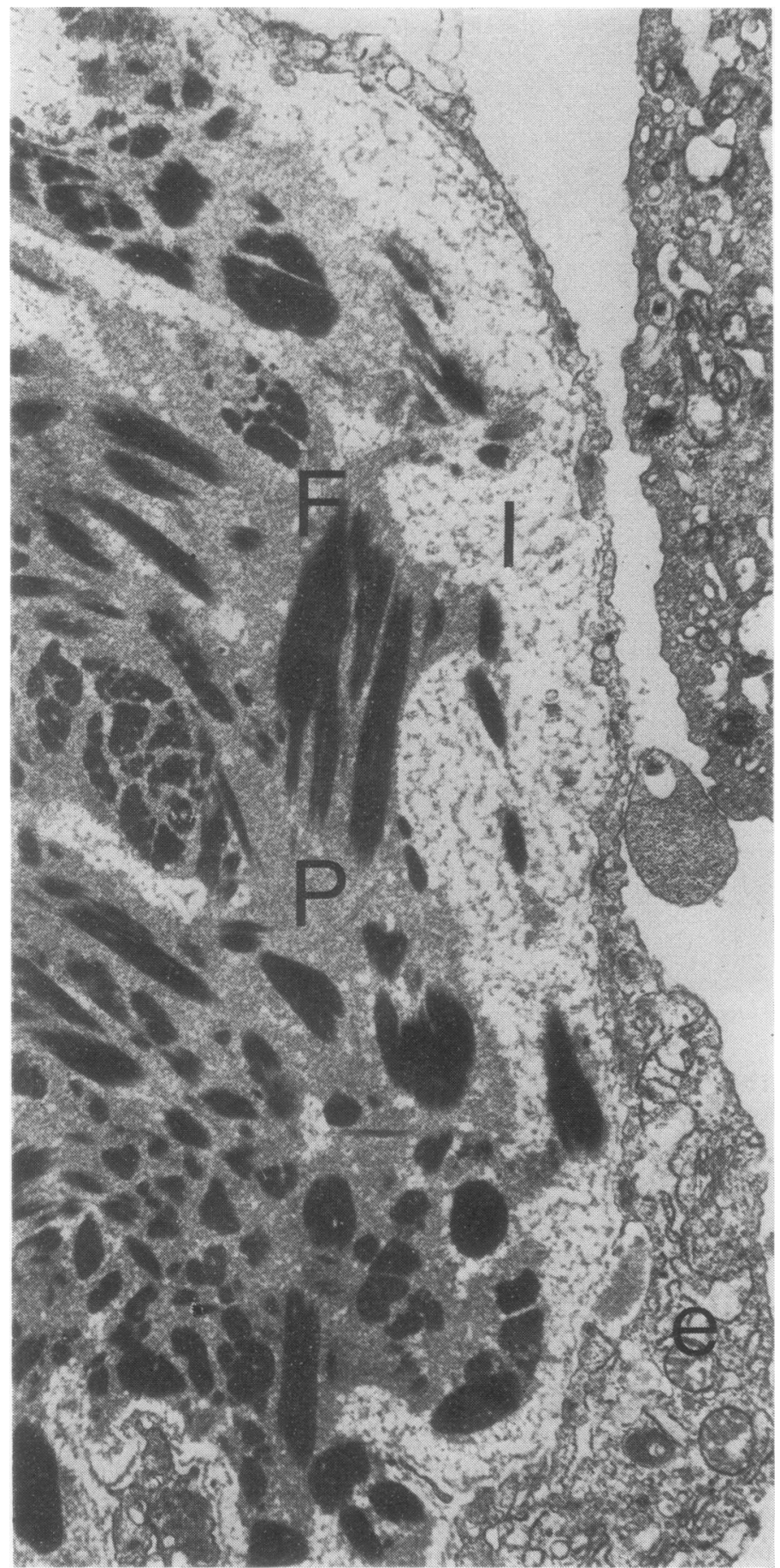

Fig 4 Muscular pulmonary artery from rat T5 showing fibrinoid necrosis.

Beneath endothelium, $e$, is a greatly widened subendothelial space, I. This contains amorphous blood plasma $(P)$ and cigar-shaped clumps of fibrin, $F$, which has a crystalline appearance. In this vessel all fibrin was confined to intima and there were several breaks in endothelium that are not shown in this figure $(E M \times 7500)$. 


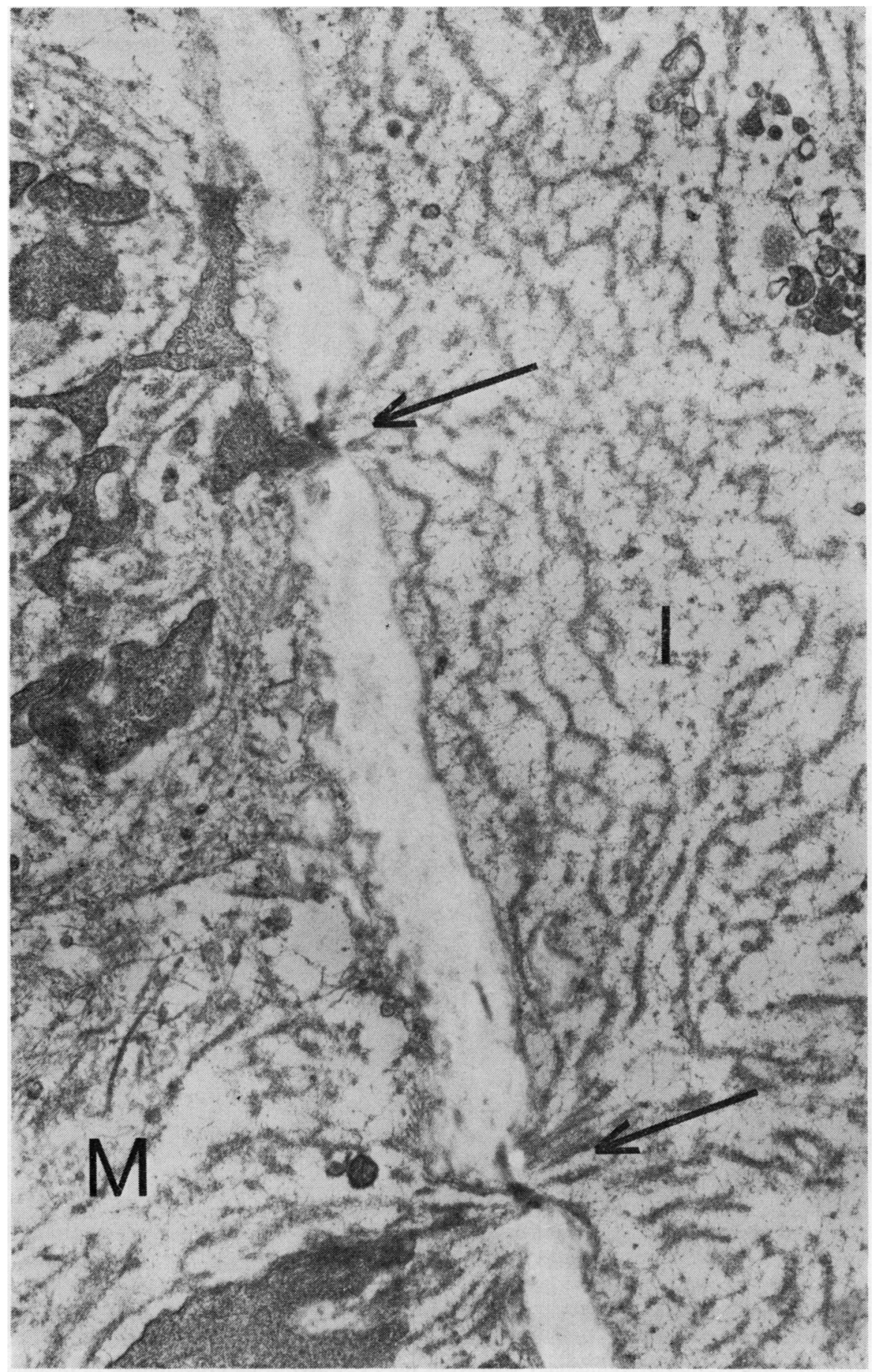

Fig 5 Part of transverse section of large muscular pulmonary artery from rat T5. In places inner elastic lamina is deficient (arrows) allowing continuity of ground substance from intima, 1 , to media, $M(E M \times 25000)$. 


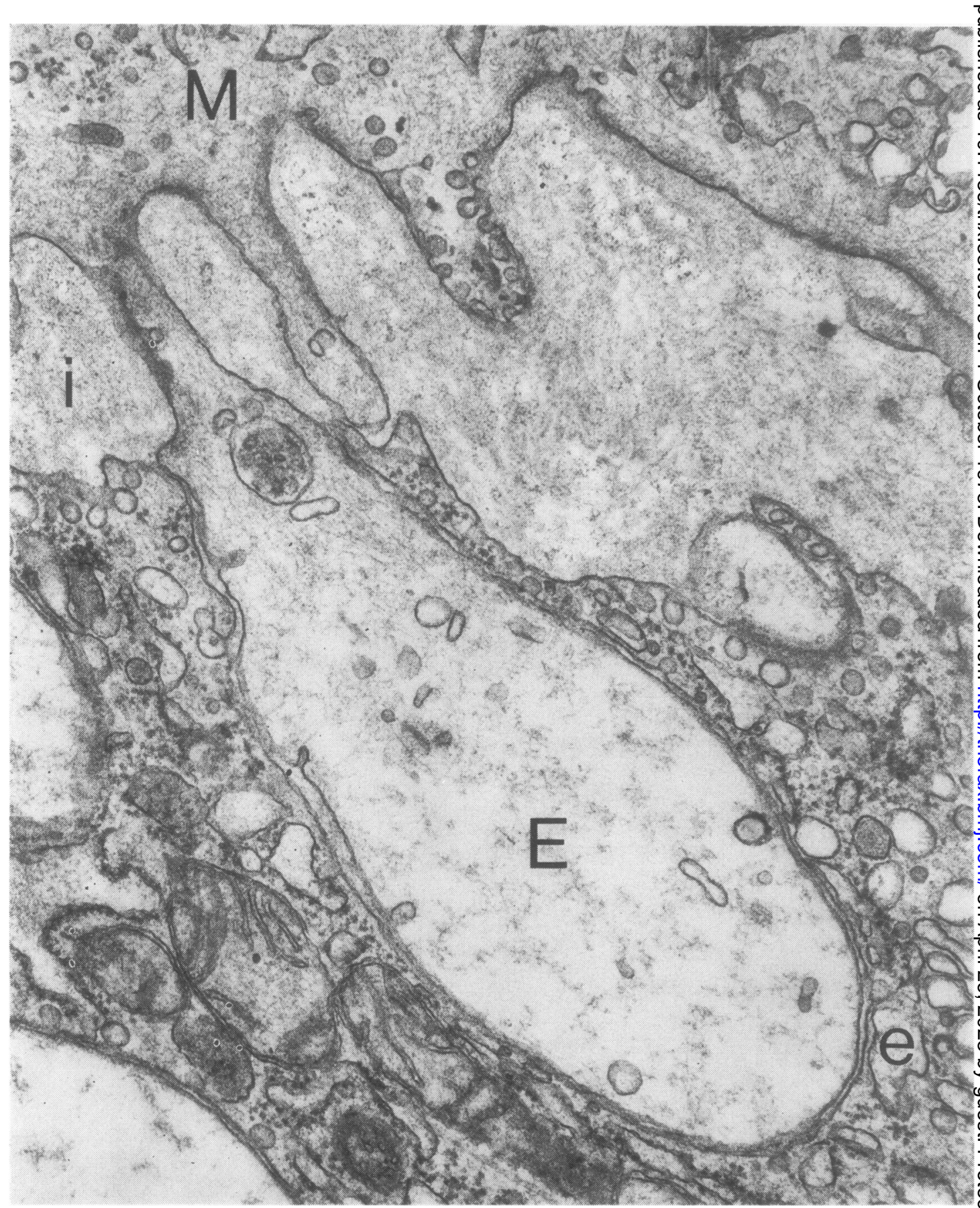

Fig 6 Part of transverse section of pulmonary vein from rat T2. There is an evagination, $E$, of smooth muscle cell, $M$, through hiatus in basal lamina, $i$. Cytoplasm of evagination is clear and devoid of myofilaments and organelles. It presses into outer part of endothelial cells, e, of intima $(E M \times 47900)$.

듬 


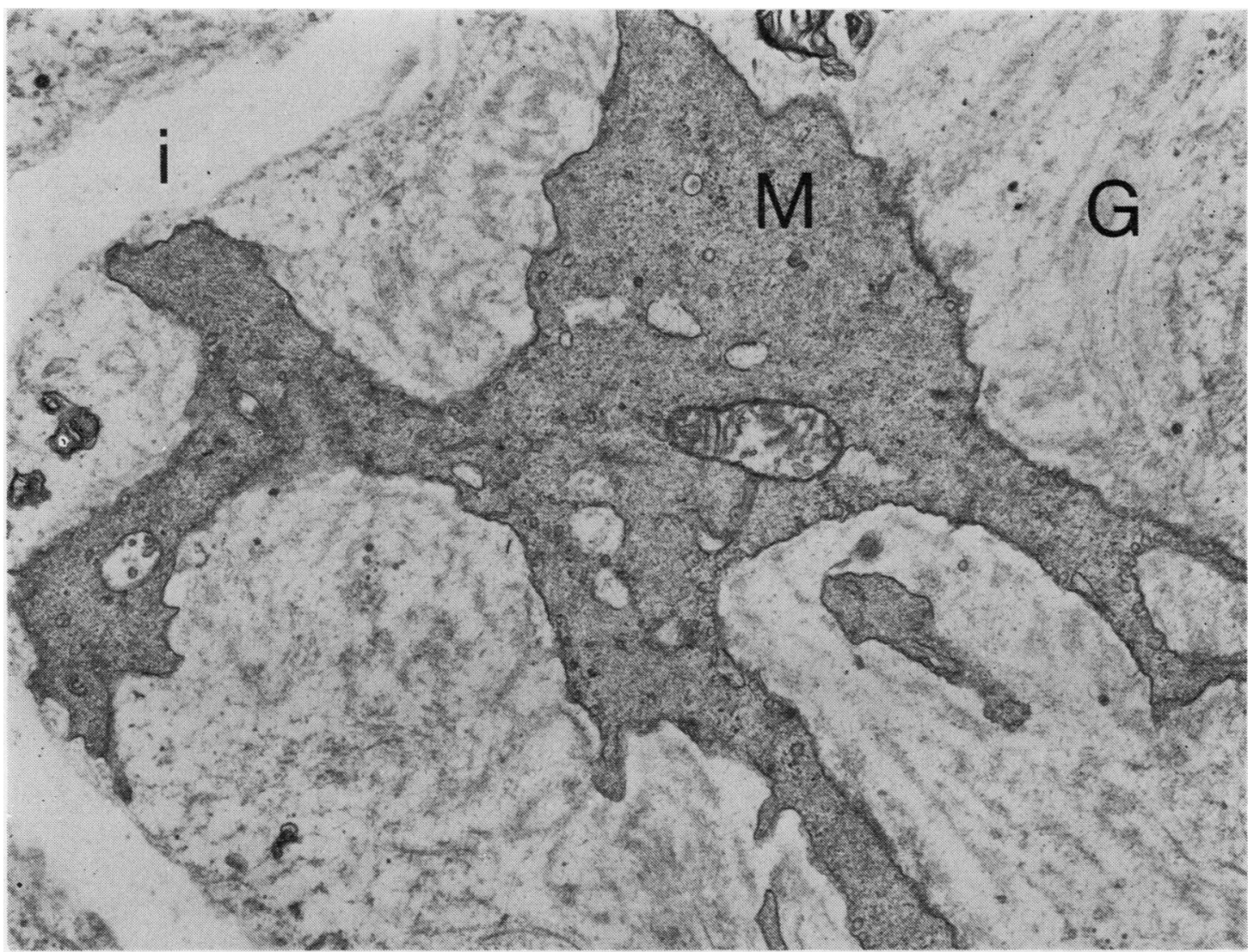

Fig 7 Muscle cell, $M$, embedded in ground substance, $G$, of swollen media and lying near inner elastic lamina, $i$. Note that this muscle cell is devoid of myofilaments while its cytoplasm is dark and granular $(E M \times .15400)$.

pulmonary arteries in the absence of necrosis. Studieston experimentally induced systemic hypertension in animals have shown that fibrinoid necrosis in renal and mesenteric arteries is similar to that in the lung. Thus muscular protrusions similar to evaginations of muscle have been described during the acute stage (Goldby and Beilin, 1972). This is followed by leakage of plasma and finely fibrillary fibrin into the subintima and inner media (Hüttner et al, 1968; Goldby and Beilin, 1972). Later the fibrin adopts the crystalline, striated appearance of "fibrinoid" (Wiener et al, 1965; Hüttner et al, 1968). There is little or no necrosis of muscle. The fibrin appears to originate from the blood by passing through ruptures in the endothelium (Koletsky et al, 1964; Wiener et al, 1965; Hüttner et al, 1968; Goldby and Beilin, 1972). Carbon particles injected into the blood stream were found to be closely associated with these fibrinous deposits (Goldby and Beilin, 1972).

Our findings show that in pulmonary hypertension induced by pyrrolizidine alkaloids ultrastructural changes occur in the smooth muscle cells of both pulmonary arteries and veins that may be ascribed to constriction. In the case of the pulmonary veins the constriction is sustained but does not lead to vascular necrosis. Its ultrastructural hallmark comprises muscular evaginations. The clear cytoplasm in these evaginations, devoid of myofilaments and organelles, is characteristic of constriction of smooth muscle as we have shown in recent publications (Smith, Heath, and Padula, 1978; Smith and Heath, 1978; Smith, Heath, and Mooi, 1978). Such ultrastructural changes, however, have to be contrasted with those that occurred in the smooth muscle cells of the media of the pulmonary arteries. These are the changes of ultrastructural damage, 


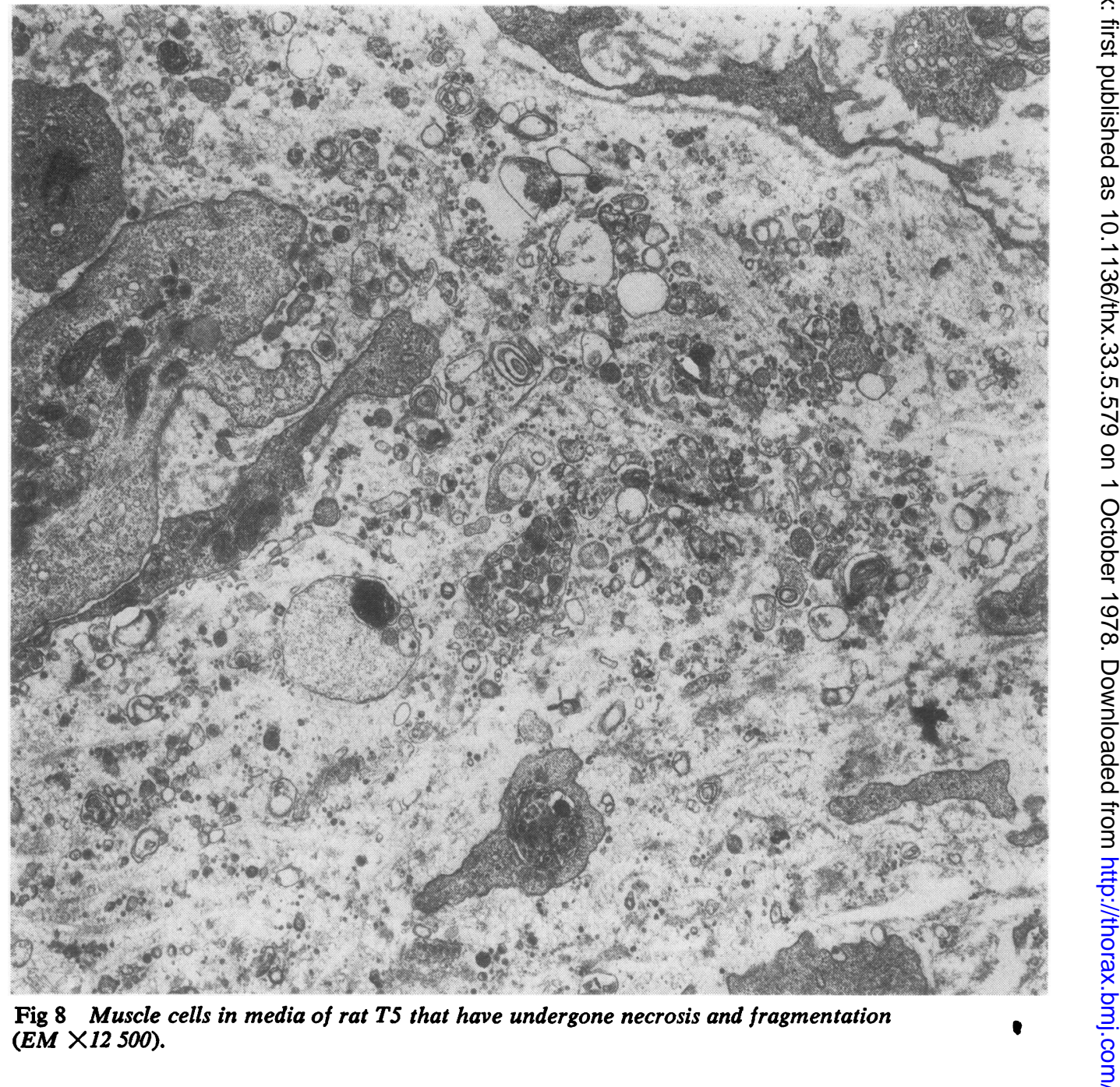

probably associated with intense vascular spasm, so that the muscle cells lose their myofilaments (fig 7). In some arteries the muscle cells then undergo necrosis with disintegration and liberation of fragments of cytoplasm and organelles into the media (fig 8). Such necrosis stimulates the infiltration of the tissues with neutrophil polymorphs, which we noted on light microscopy and confirmed on electron microscopy.

A feature of added interest in this study was the wide separation of the muscle cells by considerable accumulations of ground substance. This was recognised both by its typical ultrastructural features and by its characteristic tinctorial property for light microscopy by staining positively with alcian blue showing it to consist largely of 을 acid mucopolysaccharide. Interestingly, an excess $>$ of ground substance has been described within the media and subendothelial space of renalN arteries in experimental systemic hypertension in rats (Spiro et al, 1965). Since this material stains 0 positively with alcian blue and PAS and involvesw the incorporation of sulphate ions it is probably? a sulphated mucopolysaccharide such as chon-e droitin sulphate (Crane, 1962). Electron micro- $\bar{\Phi}$ scopy of human tissue has also shown that hyaline ${ }^{?}+$ arteriolar sclerosis of benign hypertension is com- $-\frac{T}{T}$ posed mainly of ground substance resembling $\frac{\overrightarrow{+}}{\square}$ basement membrane material (McGee and Ash- $\stackrel{\square}{\oplus}$ worth, 1963; Amano, 1977). There was much $\stackrel{\square}{\mathscr{Q}}$ 


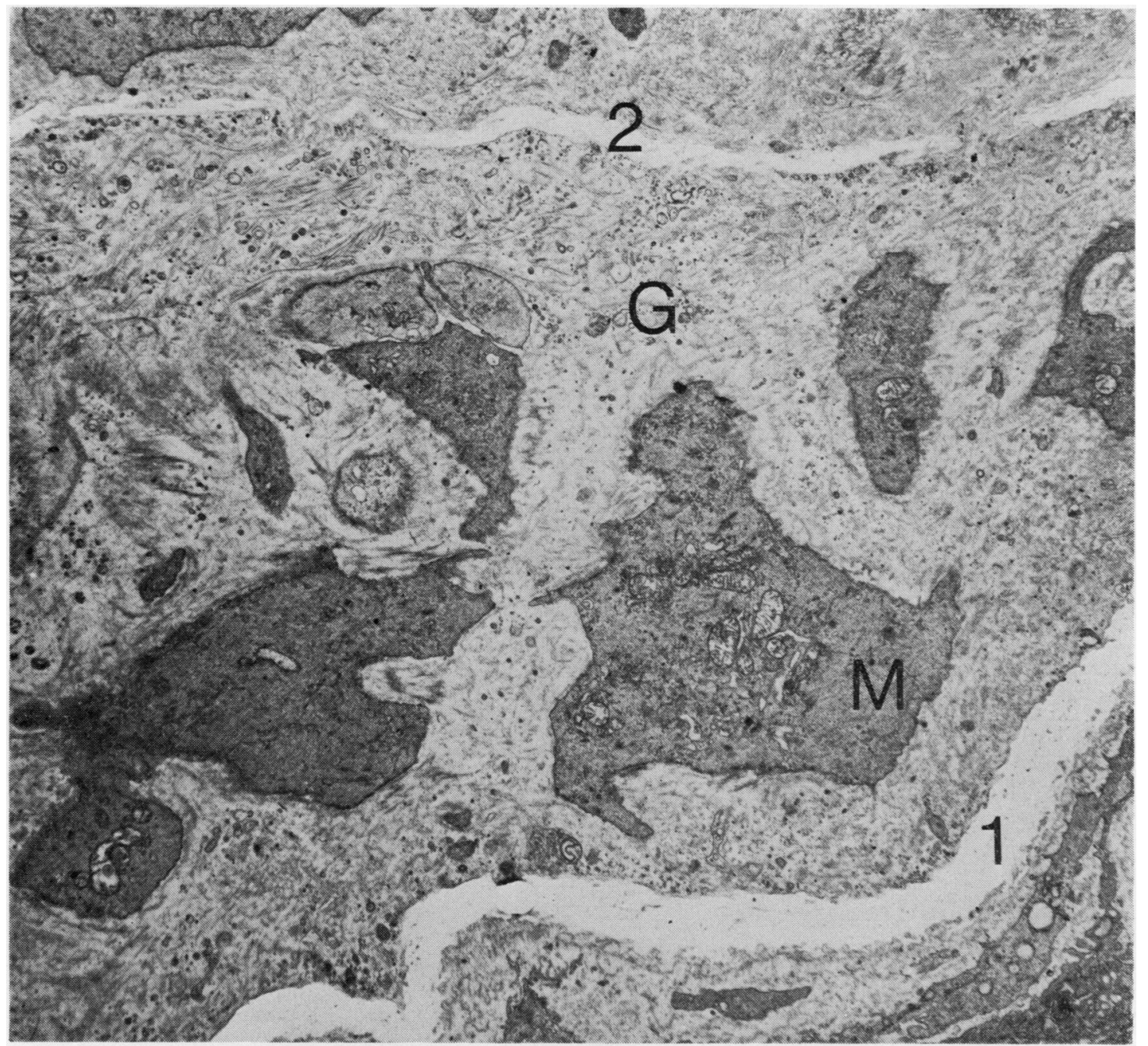

Fig 9 Part of transverse section of a muscular pulmonary artery from rat T4 showing fibrinoid necrosis. Muscle cells, $M$, are widely separated by ground substance, $G$, and collagen fibrils. Together they constitute swollen media between inner elastic lamina, 1, and outer elastic lamina, $2(E M \times 6160)$.

accumulation of small vacuoles and fine fibrils at the periphery of both fibroblasts and smooth muscle cells (fig 11) suggestive of pinocytosis. In our study it is not entirely certain which cells formed the large amounts of mucopolysaccharide but it is likely that it was "vasoformative reserve cells."

We have studied the ultrastructure of such cells before in relation to the nature of the cardiac myxoma (Stovin et al, 1973). Cells with cytoplasmic filaments are to be found commonly in the heart and great vessels. Stein et al (1969) designated them "sub-endothelial vasoformative reserve cells." They consider that they are the type cell of the cardiac myxoma but are also to be found in such conditions as the thickened endocardium overlying hypertrophied infundibular muscle in Fallot's tetrad or in the thickened aortic valve cusps in rheumatic aortic stenosis. Cells of this type with intracytoplasmic filaments resembling smooth muscle arise in thrombi (Davies et al, 1972). They appear to be closely related to the myofibroblast, which is responsible for the contractile nature of granulation tissue (Gabbiani et al, 1972). They appear to be related also to Wharton's jelly cells in the full-term umbilical 


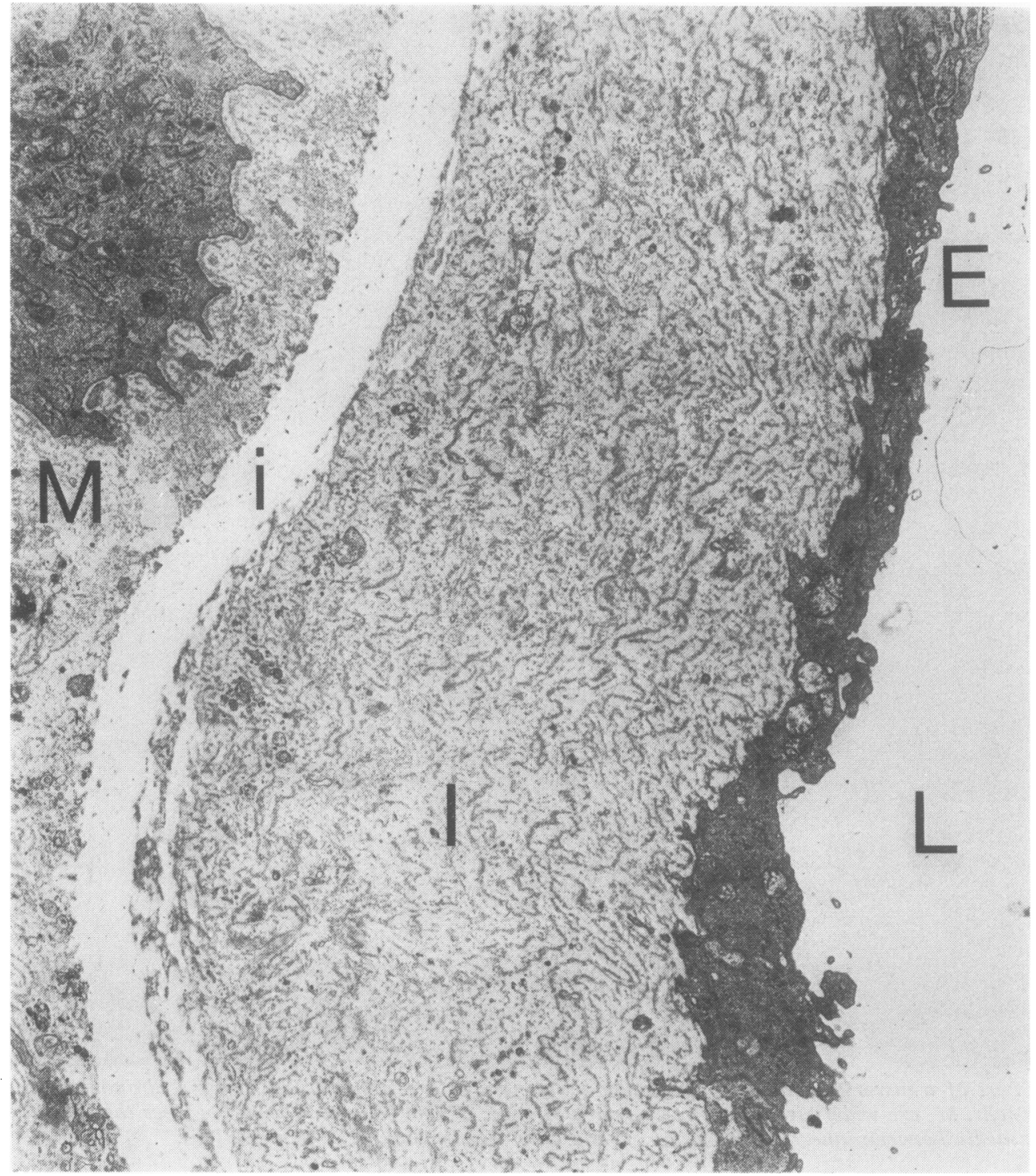

Fig 10 Part of transverse section of muscular pulmonary artery from rat T5. Lumen of vessel, $L$, is lined by endothelium, $E$, beneath which is greatly enlarged subendothelial space, $I$. This consists of numerous lamellae of ground substance that are arranged roughly concentrically. Each lamella resembles basement membrane. Beneath intima is internal elastic lamina, $i$, and media, $M(E M \times 7500)$.

cord, for Parry (1970) found that these cells contained bundles of fine filaments and thus bore a superficial resemblance to smooth muscle cells.

The origin of these vasoformative reserve cells is unclear since we have never seen them in normal pulmonary blood vessels. In many respects they resemble the cells that possess features of both fibroblasts and smooth muscle, which we ? have also described. Such cells could be termed 0 "myofibroblasts" since their ultrastructure is $\frac{O}{\Phi}$ identical to the myofibroblasts described by $\stackrel{\Omega}{\square}$ Gabbiani et al (1972). They also closely resemble $\stackrel{\mathbb{Q}}{\mathscr{Q}}$ the cells that invade the intima of arteries after endothelial damage (Buck, 1961; Poole et al, 


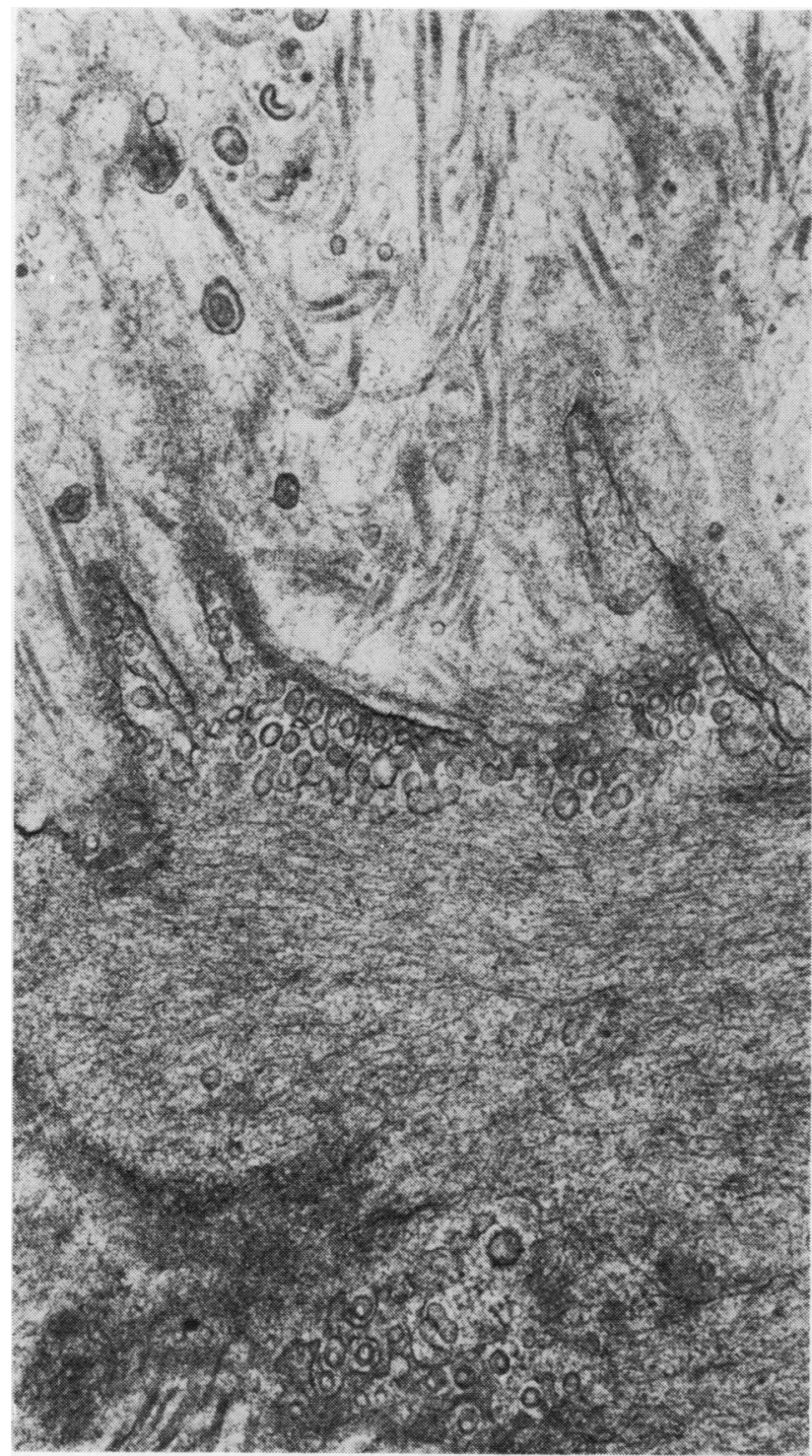

Fig 11 Part of muscle cell in media of mascular pulmonary artery. There are numerous small vesicles near its edge that are probably micropinocytotic vesicles normally found in smooth muscle. Fine fibrils extend from surface of cell and merge gradually with striated collagen fibres $(E M \times 37500)$.

1971; Stemerman et al, 1977). These have been termed "myointimal" cells (Buck, 1961) and appear to originate by migration of medial smooth muscle cells into the intima and their dedifferentiation into a cell that shares the structure of fibroblast and muscle. A similar dedifferentiation of muscle into myointimal cells occurs during the development of the atheromatous plaque (Haust et al, 1960; Thomas et al, 1963; Parker and Odland, 1966). The myofibroblasts and vasoformative reserve cells that we describe may be produced from medial smooth muscle by a similar process. In- deed, it seems not unlikely that the conglomerate of terms such as myofibroblast, vasoformative reserve cell, and myointimal cell all describe the same dedifferentiated smooth muscle. If this is so the process of smooth muscle dedifferentiation is a common denominator to many types of vascular disease.

It is likely that these vascular reserve cells can undergo hyperplasia and differentiation into smooth muscle, fibrocytes, and endothelial cells (Stein et al, 1969). Subsequently each of these cells produces its own secretion so that the differ- 


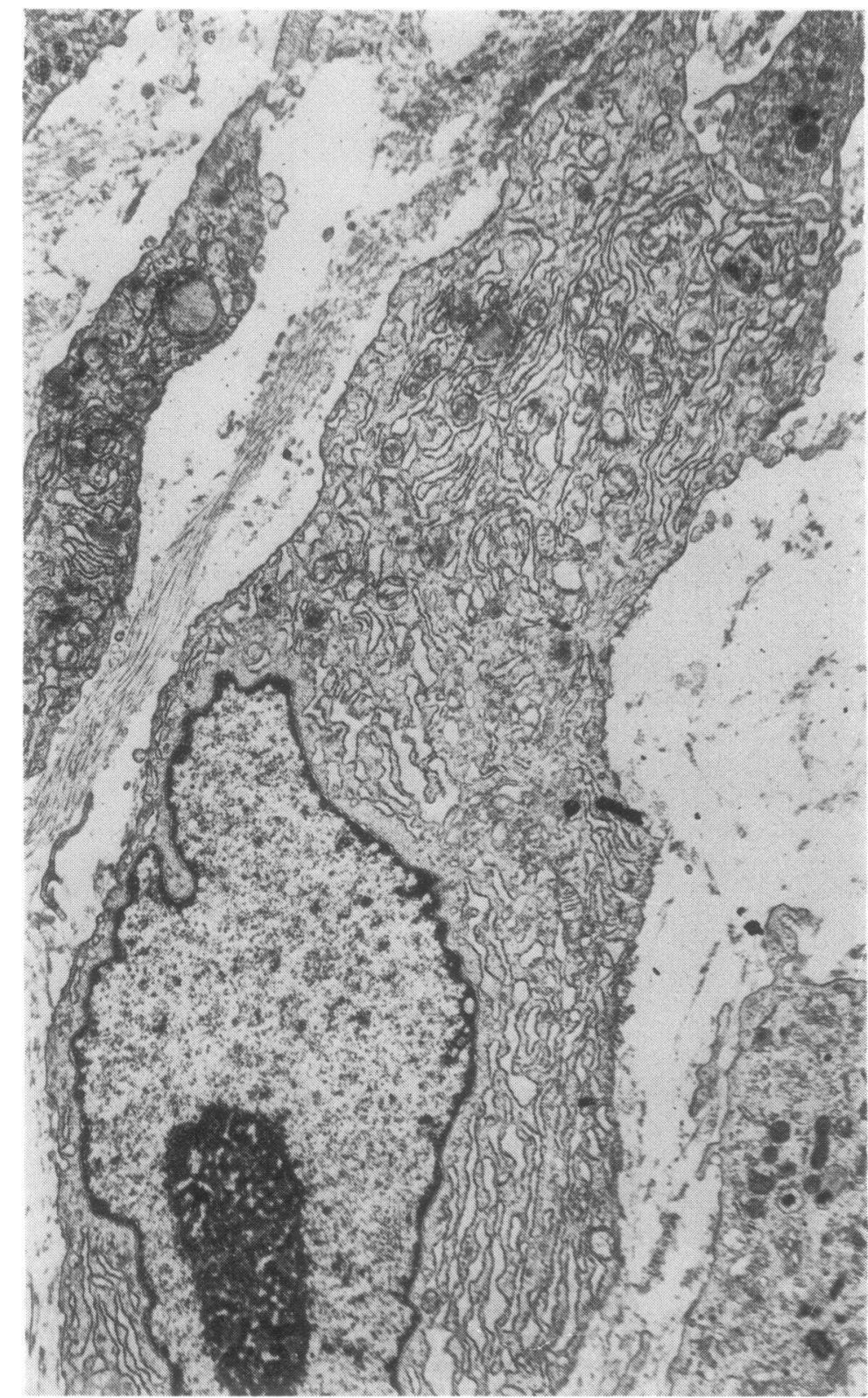

Fig 12 Fibroblast within media with characteristically profuse open endoplasmic reticulum $(E M \times 7500)$.

entiated cells become associated with a stroma containing acid mucopolysaccharide, collagen, or elastin. If this is true the liberation of these cells with such considerable and yet varied potential into the vascular wall during the process of fibrinoid necrosis is of considerable interest. May these vascular reserve cells, for example, be $\frac{T}{T}$ responsible by growth into the dilated, thin-walled $\underset{\mathbb{D}}{\vec{*}}$ vessels so characteristic of pulmonary hyper- $\frac{?}{8}$ tension, or by organisation of fibrin thrombus $\propto$ there, for the development of "the plexiform? lesion" whose nature has remained so obscure? 


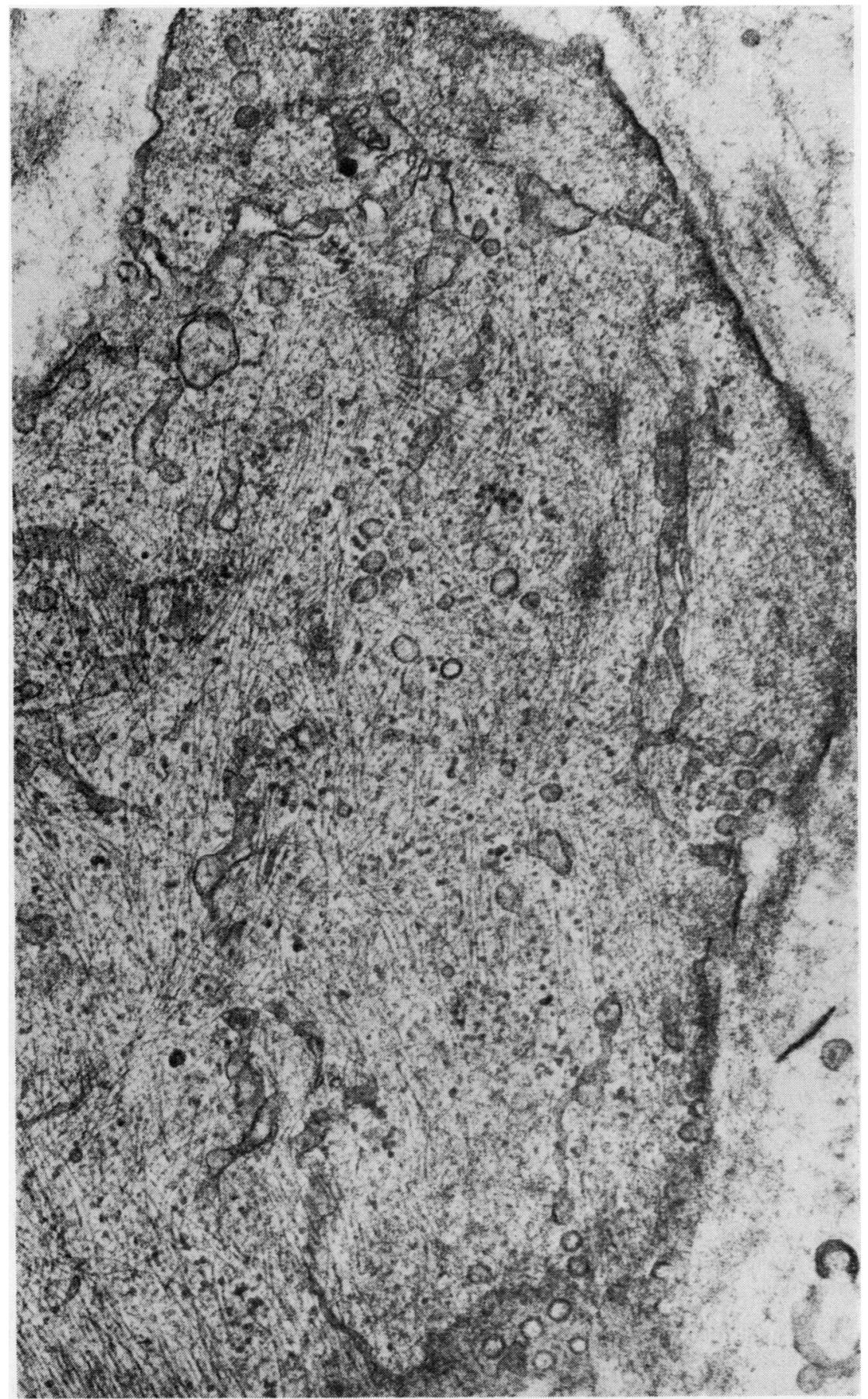

Fig 13 Part of cytoplasm of another type of cell found within media of large muscular pulmonary artery showing fibrinoid necrosis in rat T4. Cytoplasm contains numerous myofilaments running in all directions and secretory vesicles. It corresponds to what is generally termed a vasoformative reserve cell $(E M \times 50000)$. 


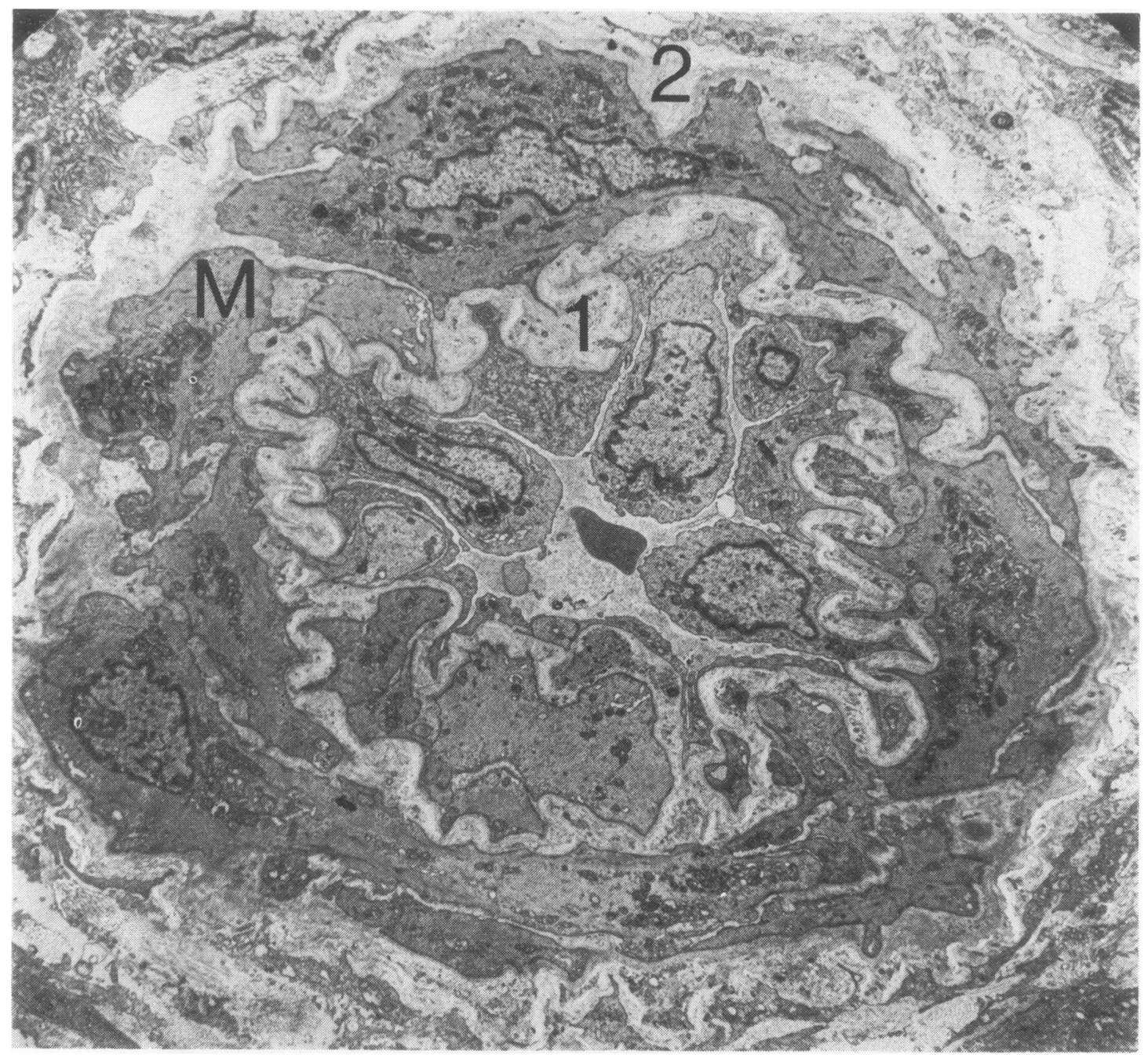

Fig 14 Transverse section of muscularised pulmonary arteriole from rat T5. Layer of smooth muscle cells, $M$, lies between internal elastic lamina, 1 , and external elastic lamina, 2. There is no fibrinoid necrosis in this vessel $(E M \times 3593)$.

\section{References}

Amano, S (1977). Vascular changes in the brain of spontaneously hypertensive rats. Hyaline and fibrinoid degeneration. Journal of Pathology, 121, 119-128.

Buck, R C (1961). Intimal thickening after ligature of arteries. Circulation Research, 9, 418-426.

Crane, W A J (1962). Sites of mucopolysaccharide synthesis in the lesions of experimental hypertension in rats. Journal of Pathology and Bacteriology, 83, 183-193.

Davies, M L, Ballantine, S J, Robertson, W B, and Woolf, $N$ (1972). An ultrastructural study of ex- perimentally induced thrombi in pig aorta. $N$ (Synopsis of paper. 125th meeting of Pathological $N$ Society of Great Britain and Ireland, Leeds.) Journal of Pathology, 107, P vi.

Elkeles, A, and Glynn, L E (1946). Disseminated 6 parenchymatous ossification in the lungs in associa- $\frac{D}{D}$ tion with mitral stenosis. Journal of Pathology and $\stackrel{?}{+}$

Bacteriology, 58, 517-522.
Gabbiani, G, Hirschel, B J, Ryan, G B, Statkov, 웅 P R, and Majno, G (1972). Granulation tissue as a $\mathbb{D}$ contractile organ. A study of structure and function. $\frac{\vec{\nabla}}{\mathrm{Q}}$ Journal of Experimental Medicine, 135, 719-734.

Gardner, D L (1970). General pathology of connective tissue and intercellular matrix. In $\boldsymbol{A}$ Companion to 8 
Medical Studies, edited by $\mathbf{R}$ Passmore and $\mathbf{J} \mathbf{S}$ Robson, vol 2, ch 30. Blackwell, Oxford and Edinburgh.

Goldby, F S, and Beilin, L J (1972). How an acute rise in arterial pressure damages arterioles. Electron microscopic changes during angiotensin infusion. Cardiovascular Research, 6, 569-584.

Hall, C E (1963). Electron microscopy of the fibrinogen molecule and the fibrin clot. Laboratory Investigation, 12, 998-1001.

Haust, M D, More, R H, and Movat, H Z (1960). The role of smooth muscle cells in the fibrogenesis of arteriosclerosis. American Journal of Pathology, 37, 377-389.

Hicks, J D (1953). Acute arterial necrosis in lungs. Journal of Pathology and Bacteriology, 65, 333343.

Hultgren, H, Selzer, A, Purdy, A, Holman, E, and Gerbode, F (1953). Syndrome of patent ductus arteriosus with pulmonary hypertension. Circulation, 8, 15-35.

Hüttner, I, Jellinek, H, and Kerényi, T (1968). Fibrin formation in vascular fibrinoid change in experimental hypertension: an electron microscopic study. Experimental and Molecular Pathology, 9, 309-321.

Koletsky, S, Rivera-Velez, J M, and Pritchard, W H (1964). Experimental renal hypertension. Origin of high blood pressure and vascular disease. Archives of Pathology, 78, 24-30.

Lendrum, A C (1955). Fibrinous vasculosis. Journal of Clinical Pathology, 8, 180.

McGee, W G, and Ashworth, C T (1963). Fine structure of chronic hypertensive arteriopathy in the human kidney. American Journal of Pathology, 43, 273-299.

Merkow, L, and Kleinerman, J (1966). An electron microscopic study of pulmonary vasculitis induced by monocrotaline. Laboratory Investigation, 15, 547-564.

Old, J W, and Russell, W O (1950). Necrotizing pulmonary arteritis occurring with congenital heart disease (Eisenmenger complex). American Journal of Pathology, 26, 789-805.

Parker, F, and Odland, G F (1966). A light microscopic, histochemical, and electron microscopic study of experimental atherosclerosis in rabbit coronary artery and a comparison with rabbit aorta atherosclerosis. American Journal of Pathology, 48, 451-481.

Parry, E W (1970). Some electron microscope observations on the mesenchymal structures of full-term umbilical cord. Journal of Anatomy, 107, 505-518.

Poole, J C F, Cromwell, S B, and Benditt, E P (1971). Behaviour of smooth muscle cells and formation of extracellular structures in the reaction of arterial walls to injury. American Journal of Pathology, 62, 391-414.

Robbins, S L (1967). Pathology, 3rd edition, pp 24 and 528. W B Saunders Co, Philadelphia, London.
Shepherd, J T, Edwards, J E, Burchell, H B, Swan, H J C, and Wood, E H (1957). Clinical, physiological, and pathological considerations in patients with idiopathic pulmonary hypertension. British Heart Journal, 19, 70-82.

Smith, P, and Heath, D (1978). Evagination of vascular smooth muscle cells during the early stages of Crotalaria pulmonary hypertension. Journal of Pathology, 124, 177-183.

Smith, P, Heath, D, and Mooi, W (1978). Observations on some ultrastructural features of normal pulmonary blood vessels in collapsed and distended lungs. Journal of Anatomy. In press.

Smith, P, Heath, D, and Padula, F (1978). Evagination of smooth muscle cells in the hypoxic pulmonary trunk. Thorax, 33, 31-42.

Spiro, D, Lattes, R G, and Wiener, J (1965). The cellular pathology of experimental hypertension. I. Hyperplastic arteriosclerosis. American Journal of Pathology, 47, 19-49.

Stein, A A, Mauro, J, Thibodeau, L, and Alley, R (1969). The histogenesis of cardiac myxomas: relation to other proliferative diseases of subendothelial vasoformative reserve cells. In Pathology Annual, edited by S C Sommers, vol 4, p 293. Butterworths, London.

Stemerman, M B, Spaet, T H, Pitlick, F, Cintron, J, Lejnieks, I, and Tiell, M L (1977). Intimal healing. The pattern of re-endothelialization and intimal thickening. American Journal of Pathology, 87, 125-137.

Stovin, P G I, Heath, D, and Khaliq, S U (1973). Ultrastructure of the cardiac myxoma and the papillary tumour of heart valves. Thorax, 28, 273285.

Symmers, W (1952). Necrotizing pulmonary arteriopathy with pulmonary hypertension. Journal of Clinical Pathology, 5, 36-41.

Thomas, W A, Jones, R, Scott, R F, Morrison, E, Goodale, F, and Imai, H (1963). Production of early atherosclerotic lesions in rats characterized by proliferation of "modified smooth muscle cells." Experimental and Molecular Pathology, 2, suppl 1, 40-61.

Wagenvoort, C A, Heath, D, and Edwards, J E (1964). The Pathology of the Pulmonary Vasculature. Charles C Thomas, Springfield, Illinois.

Wiener, J, Spiro, D, and Lattes, R G (1965). The cellular pathology of experimental hypertension. II. Arteriolar hyalinosis and fibrinoid change. American Journal of Pathology, 47, 457-485.

Requests for reprints to: Professor D Heath, Department of Pathology, New Medical School, PO Box 147, Liverpool L69 3BX.

This work was carried out with the aid of a grant from the British Heart Foundation. 